\title{
Microbes as Bioindicators for Contamination of Shatt Al-Arab Sediments in Basrah, Iraq
}

\author{
Maha K. Al-Mishrey ${ }^{1}$, Raghad Shubbar Jaafar ${ }^{2 *}$ (D) and \\ Mustafa A. Al-Dossary ${ }^{3}$ (D) \\ ${ }^{1}$ Department of Biology, College of Science,University of Basrah,Iraq. \\ ${ }^{2}$ Biological Development Department,Marine Science Center,University of Basrah,Iraq. \\ ${ }^{3}$ Department of Ecology, College of Science, University of Basrah,Iraq.
}

\begin{abstract}
Shatt Al-Arab River in Basrah, Iraq represents an important source of fresh water so the current study aimed to determine the extent of pollution of the Shatt al-Arab River with some heavy metals and hydrocarbons by measuring their concentrations in sediment samples collected from different stations along the river, as well as the adoption of biomarkers represented by bacteria and fungi in determining the extents of such pollution. The results indicate that the river is contaminated with the following metals: : $\mathrm{Ni}, \mathrm{Cr}, \mathrm{Zn}, \mathrm{Pb}, \mathrm{Cu}$ and $\mathrm{Cd}$. The total mean concentrations of heavy metals in the exchangeable part were high with $55.23,53.76,40.52,33.84,32.70$ and $14.88 \mu \mathrm{g} / \mathrm{g}$, respectively. The results also indicated a high concentration of hydrocarbons where the total mean was $\mathbf{2 8 . 5 2}$ $\mu \mathrm{g} / \mathrm{g}$. Bacteria and fungi represent vital indicators of heavy metals and hydrocarbons pollution in the environment. Different types of bacteria (Sphingomonas paucimobilis, Bacillus subtilis, Pseudomonas aeruginosa, Streptococcus thoraltensis, Staphylococcus lentus, Leuconostoc cremoris and Leuconostoc mesenteroides) and fungi (Aspergillus terreus, Aspergillus fumigatus, Aspergillus niger, Curvularia sp., Eurotium cristatus, Talaromyces flavus, Mucor sp., Rhizopus sp., Trichoderma sp., Dichotomomyces cejpii, and Penicillium spp.) have been isolated from the same sediment. Isolated of specific genera from bacteria and fungi like these isolated in the present study from the sediment of all studied stations reinforces the rest of the results recorded during the current study and confirms the pollution of the river with the studied pollutants.
\end{abstract}

Keywords: Shatt Al-Arab River, Bacteria, Fungi, Heavy metals, Hydrocarbons

*Correspondence: raghad.jaafar@uobasrah.edu.iq

(Received: May 28, 2021; accepted: June 28, 2021)

Citation: Al-Mishery MK, Jaafar RS, Al-Dossary MA. Microbes as Bioindicatos for Contamination of Shatt Al-Arab Sediments in Basra, Iraq. J Pure Appl Microbiol. 2021;15(3):1362-1370. doi: 10.22207/JPAM.15.3.26

(C) The Author(s) 2021. Open Access. This article is distributed under the terms of the Creative Commons Attribution 4.0 International License which permits unrestricted use, sharing, distribution, and reproduction in any medium, provided you give appropriate credit to the original author(s) and the source, provide a link to the Creative Commons license, and indicate if changes were made. 


\section{INTRODUCTION}

Often the environment exposed to major disturbances resulting from the rapid development of industrial and urban activities. These activities lead to human-origin impacts as a result of acute or chronic sources of pollution. Evidence indicates that heavy metal and hydrocarbon pollution have the largest environmental impact ${ }^{1}$. Usually, these types of pollutants find their way into water and have long life, since these pollutants are insoluble? Pollutants tend to settle in the sediment of river, due to the sediments' ability to absorb these substances and deposit them between their particles ${ }^{3}$. Studying the chemical analysis of sediment in the river is therefore a useful way to study environment pollution, that the sediment is considered as recorder for watersheds enteric environment. The sediment that formed during weathering usually changes their composition during adsorption of chemical anthropogenic souces ${ }^{4}$.

The influx of pollutants from various waste sources leads to change in the environment, and especially affects the quality of water, sediment and air, which is reflected on the biological components of the environment, such as plants, animals and microorganisms $s^{5}$. There are different physical, chemical and biological criterias that can be utilized to determine the quality of the environment ${ }^{6}$. Recently, biological parameters such as bacteria and fungi are widely used to detect the quality of environment as they can give evidence to the presence of pollutants in the environment. In the aquatic environment, these microbial indicators are often associated with the sediment fraction ${ }^{7}$. This association is due to three natural achievements of the sediment which are: 1 . providing suitable condition for microbial attachment, 2. representing source of organic matters and nutrients for microbes, 3. and also is considered as a source of protection against sunlight and ultraviolet rays which constitute environmental stress ${ }^{7}$. There are many studies that confirmed the survival of bacteria in sediments for longer life than their age within the water column of both freshwater and marine water. Real association between the number and the type of bacteria through the water column of seawater and sediments have been observed in the previous studies ${ }^{7,8}$. The study conducted found more indicator organisms in sediments than in water and assumed that it is the defense actions for sediments ${ }^{7}$.

Many studies have been done to determine the degree of pollution in the environmental ecosystem using microbes ${ }^{9}$ conducted ability of community of soil microbial to reflect the amount of pollution in the soil as well as the impact of heavy metal concentration on the soil ecology. ${ }^{10}$ Indicated the ability of filimantous fungi to tolerance high levels of heavy metals. ${ }^{11}$ isolated different genera of fungi, Fusarium sp, Trichoderma sp, Aspergillus sp and Rhizoctonia $\mathrm{sp}$, while the most isolated bacteria was Bacillus sp. from heavy metals polluted soil. These species except Rhizoctonia sp. responded to the presence of heavy metals in the soil and may thus serve as microbial indicator species. Also different studies indicated the relation between bacteria and fungi and hydrocarbons pollution ${ }^{12}$ identified nine bacterial species and seven fungal species from oil polluted site in Effurun, Nigeria. Additionally, another study found five bacteria from diesel contaminated soil, in petroleum filling station at Nadapuram, Kozhikode District, Kerala ${ }^{13}$.

For the importance of water environments and because of the different pollutants which enter to such environments from multiple sources, and considering that vital monitoring is the most accurate in giving the clearest envisage of the reality of pollution in an environment, the current study has adopted bioindicators (bacteria and fungi) isolated from the studied environment as an indicator of the pollution of the Shatt Al-Arab River with both heavy metals and hydrocarbons

\section{MATERIALS AND METHODS Description to the Shatt Al-Arab River}

The Shatt Al-Arab river has a total length reach to a about $192 \mathrm{Km}$ the first $100 \mathrm{Km}$ of the river course situated entirely within the Iraqi territories : only the last $\sim 90 \mathrm{~km}$ of the river constitutes the border between Iran and Iraq, it widens over its course, expanding from a width of (250-300) $m$ near the Euphrates-Tigris confluence to almost $700 \mathrm{~m}$ near the city of Basrah and more than $800 \mathrm{~m}$ as it approaches the river mouth An area of $145,190 \mathrm{~km} 2$ drains directly to the Shatt Al-Arab region downstream of the Euphrates-Tigris confluence (excluding the Euphrates and Tigris 
Basin areas $)^{14}$. The Shatt Al-Arab Delta area is classified as estuarine-deltaic because the river's sediment seeps into a shallow, narrow part of the Arabian Gulf. The Shatt al Arab Delta is $140 \mathrm{~km}$ wide and splits into more than 10 branches. The landscape is characterized by green marshy areas, lakes, lagoons and estuaries, bordered by irrigated lands and date palm plantations and surrounded by desert (UN-ESCWA and BGR 2013). Shatt ALArab depends on some water sources tributaries for feeding. These tributaries are Al-Hammar, Al-Huyaza and Al-Qurna marshes and Al-Karoon
River which flows in its left side. Shatt AL-Arab also affected by the climate tide comes from Arabian Gulf which reduces discharge of Shatt AL-Arab water to the sea. Shatt AL-Arab's two banks are characterized to be low in its flow area reaching Basrah, its full with water channels which are used for irrigation agriculture land ${ }^{15}$.

\section{Study Stations}

Six sites in Shatt Al-Arab River were chosen to obtain sediment samples as represented in Table 1. Fig. 1 shows the coordinates of the sample locations.

Table 1. The name and the coordination of studied stations

\begin{tabular}{llll}
\hline $\begin{array}{l}\text { Samples } \\
\text { numbers }\end{array}$ & $\begin{array}{l}\text { Sampling } \\
\text { station }\end{array}$ & Latitude & Longitude \\
\hline 1 & Al-Qurna & $30-58-28.81 \mathrm{~N}$ & $47-28-33.81 \mathrm{E}$ \\
2 & Al-Deer & $30.7987835 \mathrm{~N}$ & $47.5742088 \mathrm{E}$ \\
3 & Al-Qarma & $33.4364631 \mathrm{~N}$ & $43.9627492 \mathrm{E}$ \\
4 & Al-Ashar & $30.31 .08 .68 \mathrm{~N}$ & $47.50 .46 .25 \mathrm{E}$ \\
5 & Abu-Alkasib & $302736.98 \mathrm{~N}$ & $480131.64 \mathrm{E}$ \\
6 & Al-Fao & $29.58 .57 .66 \mathrm{~N}$ & $48.28 .36 .62 \mathrm{E}$ \\
\hline
\end{tabular}

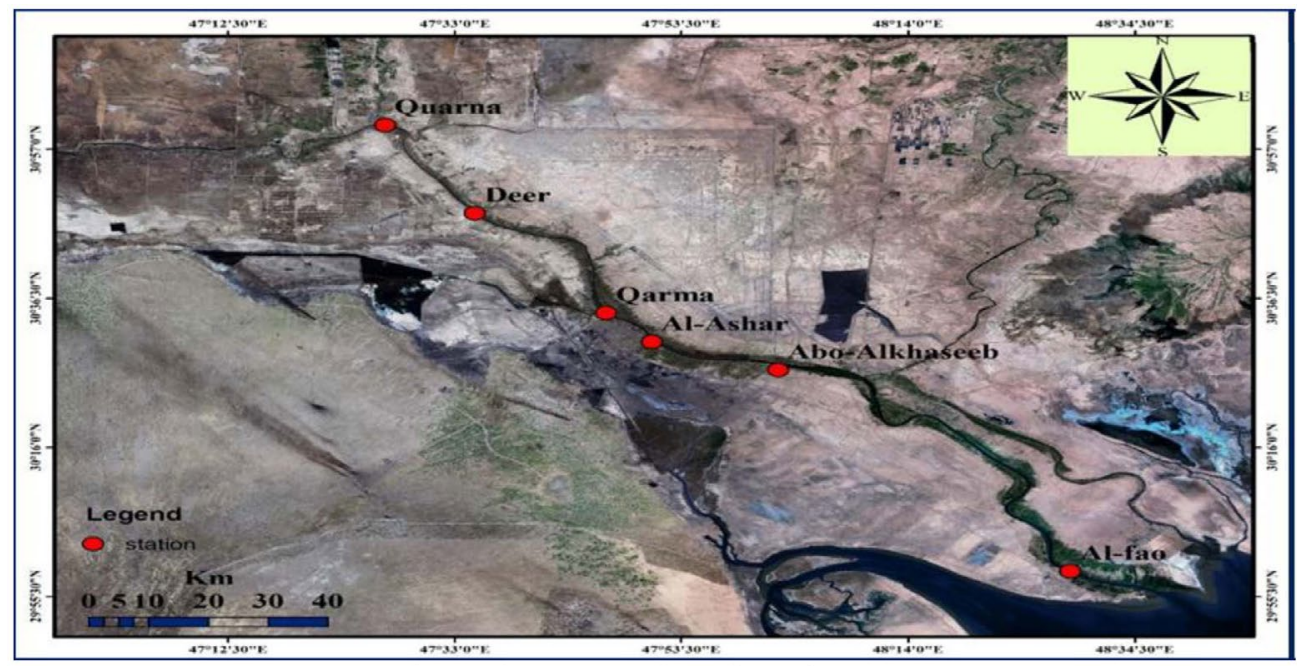

Fig. 1. The location of studied area

\section{Sediments sampling and analysis}

Six stations in Shatt Al-Arab River were chosen to collect the sediment samples (Table 1). The sampling period was from 2019 until 2020. Samples were collected to measure the concentration of heavy metals $\mathrm{Cr}, \mathrm{Co}, \mathrm{Cd}, \mathrm{Cu}$,
$\mathrm{Pb}, \mathrm{Ni}, \mathrm{Fe}$ and $\mathrm{Zn}$ ) in both exchangeable and residual phases. The exchangeable heavy metal ions were extracted from sediment, according to the method from the previous study ${ }^{16}$, while the residual heavy metals were extracted according to another study ${ }^{17}$. Flame Atomic Absorption 
Spectrophotometer (FAAS) was used to measure the concentration of the studied metals. A method from the previous study ${ }^{18}$ was followed to measure the total organic carbon in the sediment. The extraction method of petroleum hydrocarbons followed another study ${ }^{19}$.

\section{Isolation and identification of bacteria}

One gram of air-dried sediment sample was diluted (using) sterilized deionized water sequently and plated over a nutrient agar plate before being incubated at $30^{\circ} \mathrm{C}$ for $24 \mathrm{hr}$. Pure isolated bacterial cultures were identified based on the following characteristics such as colony altitude, size, form, color and texture gram stain reaction then identify by Vitek II (Biomerieux, USA).

\section{Isolation and Identification of fungi}

The dilution technique was followed to isolate fungi from sediment. Briefly, $10 \mathrm{~g}$ from each sediment sample was added into $100 \mathrm{~mL}$ of sterile physiological saline solution, shaken for ten min and diluted up to $\times 10^{4}$. For each dilution, Approximately $1 \mathrm{ml}$ from each dilution was transferred to a sterile Petri dish, to which $15 \mathrm{ml}$ of sterile medium was added. The components of the Petri dish were mixed well before solidification, and the Petri dish was incubated at $25^{\circ} \mathrm{C}$ for 2 week. For primary isolation, Malt Extract Agar (MEA), and Potato Dextrose Agar (PDA) media supplemented with chloramphenicol (50 ppm) were used. The plates were then incubated for 5-7 days at $25^{\circ} \mathrm{C}$ till the growth of fungal colonies appeared. Morphologically distinct colonies were selected and further purified by sub-culturing them on plates containing PDA. The pure isolates were identified according to their micro- and macroscopic structures. The growth pattern, pigmentation and colony morphology were observed during the incubation period for the identification of fungi. The pure isolates were identified up to genus level based on the macroand the micro-morphological characters following previous studies ${ }^{20,21}$.

\section{RESULTS AND DISCUSSION \\ Hydrocarbons Concentration}

There are many sources of hydrocarbon pollution in the environment, as they may be transmitted through the atmosphere or as a result from crude oil and refined products, and also from plant effluent or municipal waste ${ }^{22}$. Sediments are the final settlement for hydrocarbon pollutants, as they latter tend to bind to suspended particles in the aquatic environment. Consequently, the sediment components of these pollutants can determine their various sources, either natural or as a result of human activities ${ }^{23}$.

Table 2 shows the means of the total concentration of hydrocarbons in the studied regions where the means were ranged from 19.55 to $37.03 \mu \mathrm{g} / \mathrm{g}$. The result indicated the highest concentrations of hydrocarbons with the following order: Al-Ashar < Abu-Alkasib < Al-Garma < AlDeer $<$ Al-Fao < Qurnah. Shat Al-Arab River is one of the main rivers flowing through Basrah and it represents the main waterway in the city. Al-Ashar, Abu-Alkasib and Al-Garma are cities located along the river that runs through the areas that are most densely populated, high commercial and high industrial. Correspondingly, higher potential for hydrocarbons loading from this region was observed.

Table 2. The mean concentration of hydrocarbons with SD

\begin{tabular}{lc}
\hline Stations & $\begin{array}{c}\text { Mean of concentration } \\
(\mu \mathrm{g} / \mathrm{g}) \text { With SD }\end{array}$ \\
\hline Al-Deer & $27.74 \pm 0.82$ \\
Qurnah & $19.55 \pm 0.86$ \\
Al-Garma & $31.70 \pm 0.51$ \\
Ashar & $37.03 \pm 0.82$ \\
Abu Al-Khaseeb & $33.47 \pm 0.86$ \\
Al-Fao & $21.68 \pm 0.65$ \\
Total of mean & $28.52 \pm 6.46$ \\
\hline
\end{tabular}

\section{Heavy metals in the exchangeable part}

Study the exchangeable form of heavy metal in the sediment is a very important approach to assess the river pollution. Sediments usually act as carriers for heavy metals in the hydrological rotation and because metals are distributed into the surrounding waters, they reflect the quality of the water system ${ }^{24}$. The total concentration of heavy metal can not reflect the exact risk of pollution with such pollutants that the fit assessment of heavy metals pollution depends on their bio-availability ${ }^{25}$. The exchangeable concentrations of heavy metals in the studied station are shown in Table 3. The concentrations 
showed significant differences between the sampling sites $(P \leq 0.05)$, and the average metal levels are in the following order: $\mathrm{Ni}>\mathrm{Cr}>\mathrm{Zn}<$ $\mathrm{Pb}<\mathrm{Cu}>\mathrm{Cd}$. Further result indicated that the concentration of studied metals took the following order in related to the studied stations: Al-Ashar < Al-Garma < Abu-Alkasib > Al-Dayr < Al-Fao < Al-Qurna. The result may be due to direct toxic chemicals discharged into the river and the shipbreaking activities. ${ }^{26}$

\section{Heavy metals in the residual parts}

The important form of heavy metals in the environment is related to its bioavailability, and heavy metals bioavailability decrease in the order of exchangeable < residual. A residual form of heavy metals represents the geochemical background values for the metals in the sediments, which can not mobilize and not toxic. The high level of residual fraction reflects the good indicator for safe and non toxic environment, which means positive development and long period of metal deposition ${ }^{27}$. Table 4 shows the mean concentration of the studied metals in the residual particles. From results, we can conclude that the composition of the heavy metals followed this order: $\mathrm{Ni}<\mathrm{Cr}>\mathrm{Zn}>\mathrm{Pb}<\mathrm{Cu}<\mathrm{Cd}$, while the heavy metals concentrations according to stations followed the order of this: Al-Ashar < Al-Garma <
Abu-Alkasib < Al-Fao < Al-Dayr < Al-Qurna. The result showed significant differences between the stations $(P \leq 0.05)$, and this order can be explained by the reduced pollution sources in the last station. The pollution resulting from sewage, industrial, oil pollution (Al-Muftia oil refineries) and municipal wastes were responsible for the high amount of pollution ${ }^{18}$. In general, it is in high amout in comparision with the exchangeable part for all the studied stations, reducing the risk of heavy metals pollution. Table 5 show the the concentration of heavy metals in the Shatt Al-Arab river recorded in previous study through long period of time.

\section{Bacterial \& fungal identifications}

Microorganisms are used as friendly indicators for pollution in both of aquatic and terrestrial ecosystems as they are easy to be assessed and readily available ${ }^{37}$. Different groups and species of bacteria can be used as bioindicators that the specific presence of some bacterial species in the environment in large numbers indicate the presence of pollutants. In addition, some bacterial behavior can be observed to identify the presence of pollutant. For instance, bacteria produce stress protein when exposed to cadmium ${ }^{38}$. Recently, bacterial markers in aquatic ecosystems are important in bacterial identifications ${ }^{38}$. The present study identified

Table 3. The mean Concentration $(\mu \mathrm{g} / \mathrm{g}) \pm \mathrm{SD}$ of Exchangable part of studied metals in the studied stations

\begin{tabular}{lcccccc}
\hline Stations & $\mathrm{Ni}$ & $\mathrm{Cr}$ & $\mathrm{Zn}$ & $\mathrm{Pb}$ & $\mathrm{Cu}$ & $\mathrm{Cd}$ \\
\hline Al-Deer & $50.75 \pm 0.45$ & $50.93 \pm 0.10$ & $36.81 \pm 0.59$ & $30.91 \pm 0.55$ & $24.70 \pm .20$ & $12.27 \pm 0.48$ \\
Qurnah & $45.17 \pm 0.40$ & $45.18 \pm 0.39$ & $31.39 \pm 0.774$ & $28.79 \pm 0.80$ & $18.22 \pm 0.020$ & $9.62 \pm 0.37$ \\
Al-Garma & $63.44 \pm 0.51$ & $63.32 \pm 0.45$ & $50.96 \pm 1.24$ & $35.04 \pm 0.71$ & $46.22 \pm 0.54$ & $16.80 \pm 0.52$ \\
Al-Ashar & $66.22 \pm 0.51$ & $58.43 \pm 0.49$ & $47.33 \pm 1.02$ & $41.06 \pm 0.19$ & $47.94 \pm 0.31$ & $21.81 \pm 0.75$ \\
AbuAl-Khaseeb & $54.70 \pm 0.79$ & $54.66 \pm 0.56$ & $40.68 \pm 0.82$ & $35.00 \pm 0.30$ & $36.87 \pm 0.58$ & $18.07 \pm 0.42$ \\
Al-Fao & $51.08 \pm 0.16$ & $50.06 \pm 0.22$ & $35.95 \pm 0.46$ & $32.26 \pm .55$ & $22.27 \pm 0.38$ & $10.72 \pm 0.42$ \\
Total of Mean & $55.23 \pm 7.60$ & $53.76 \pm 6.08$ & $40.52 \pm 6.98$ & $33.84 \pm 4.04$ & $32.70 \pm 11.99$ & $14.88 \pm 4.49$ \\
\hline
\end{tabular}

Table 4. The mean Concentration $(\mu \mathrm{g} / \mathrm{g}) \pm \mathrm{SD}$ of Residual part of studied metals in the studied stations

\begin{tabular}{|c|c|c|c|c|c|c|}
\hline Stations & $\mathrm{NI}$ & $\mathrm{Cr}$ & $\mathrm{Zn}$ & $\mathrm{Pb}$ & $\mathrm{Cu}$ & $\mathrm{Cd}$ \\
\hline Al-Deer & $63.02 \pm 0.21$ & $62.79 \pm 0.54$ & $50.56 \pm 0.56$ & $37.76 \pm 0.86$ & $24.70 \pm 0.20$ & $25.28 \pm 0.50$ \\
\hline Qurna & $61.26 \pm 0.31$ & $60.88 \pm 0.37$ & $44.13 \pm 0.97$ & $35.67 \pm 0.50$ & $18.22 \pm .02$ & $13.20 \pm 0.24$ \\
\hline Al-Garma & $69.71 \pm 0.79$ & $70.78 \pm 0.36$ & $62.47 \pm 0.95$ & $41.40 \pm 0.77$ & $58.31 \pm 0.59$ & $18.24 \pm 0.29$ \\
\hline Al-Ashar & $73.08 \pm 0.45$ & $75.56 \pm 0.89$ & $58.33 \pm 0.67$ & $46.02 \pm 0.64$ & $58.35 \pm 3.17$ & $20.80 \pm 0.72$ \\
\hline AbuAl-Khaseeb & $68.22 \pm 0.52$ & $59.87 \pm 0.82$ & $56.66 \pm 1.02$ & $38.35 \pm 0.65$ & $46.67 \pm 0.49$ & $20.48 \pm 0.89$ \\
\hline Al-Fao & $64.15 \pm 1.65$ & $63.70 \pm 0.96$ & $55.51 \pm 0.72$ & $38.94 \pm 1.08$ & $33.86 \pm 0.64$ & $14.17 \pm 0.40$ \\
\hline Total of mean & $66.57 \pm 4.28$ & $65.60 \pm 5.86$ & $54.61 \pm 6.08$ & $39.69 \pm 3.45$ & $40.02 \pm 16.10$ & $66.57 \pm 4.26$ \\
\hline
\end{tabular}




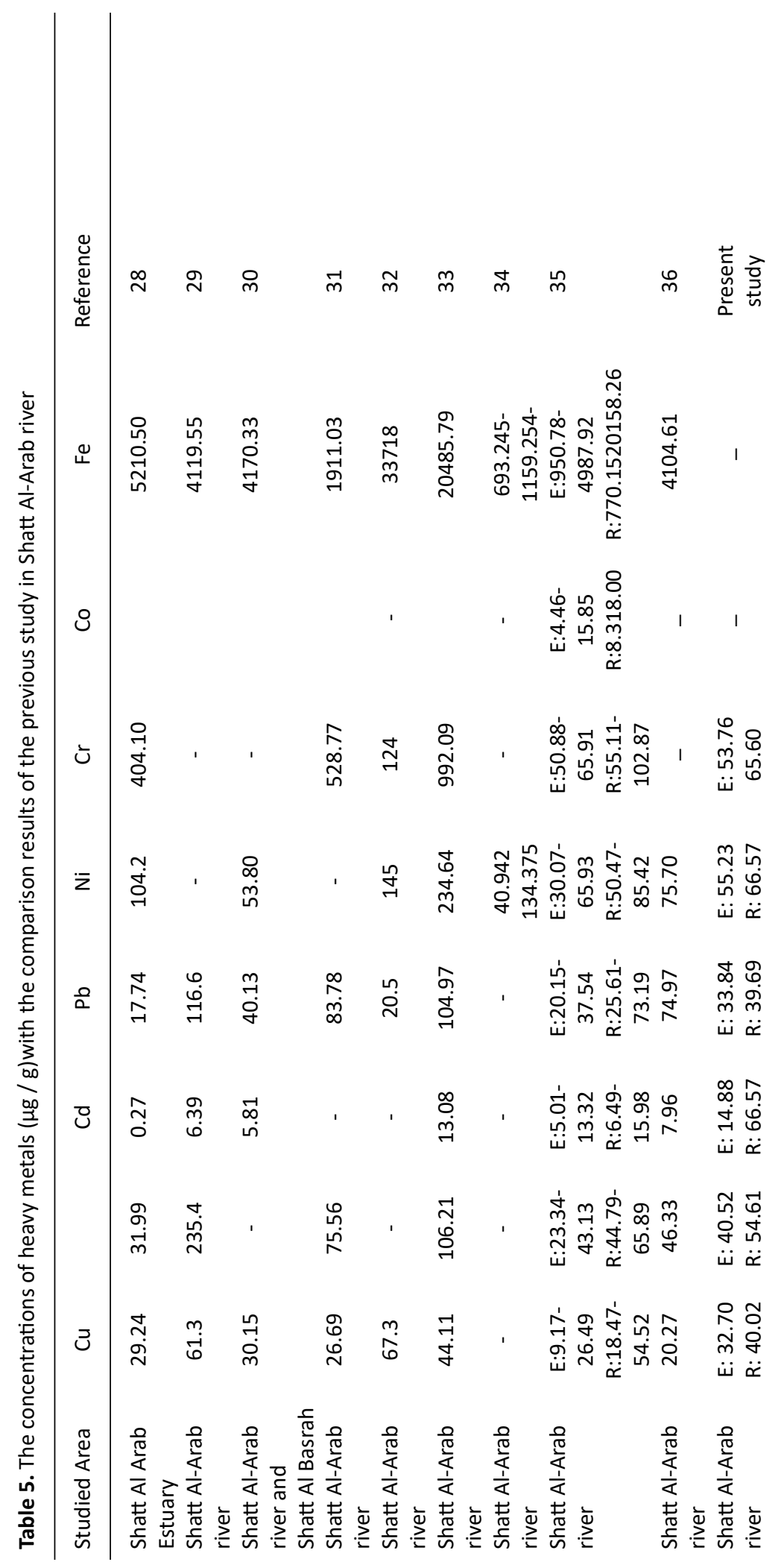

Journal of Pure and Applied Microbiology

1367 
bacteria morphologically (Fig. 2), as well as by using the automated instrument (Vitek II). This instrument gave identifiable accuracy up to $95 \%$ confidence level (Table 6).The results of the present study are in agreement with the findings of the previous studies ${ }^{39-42}$.
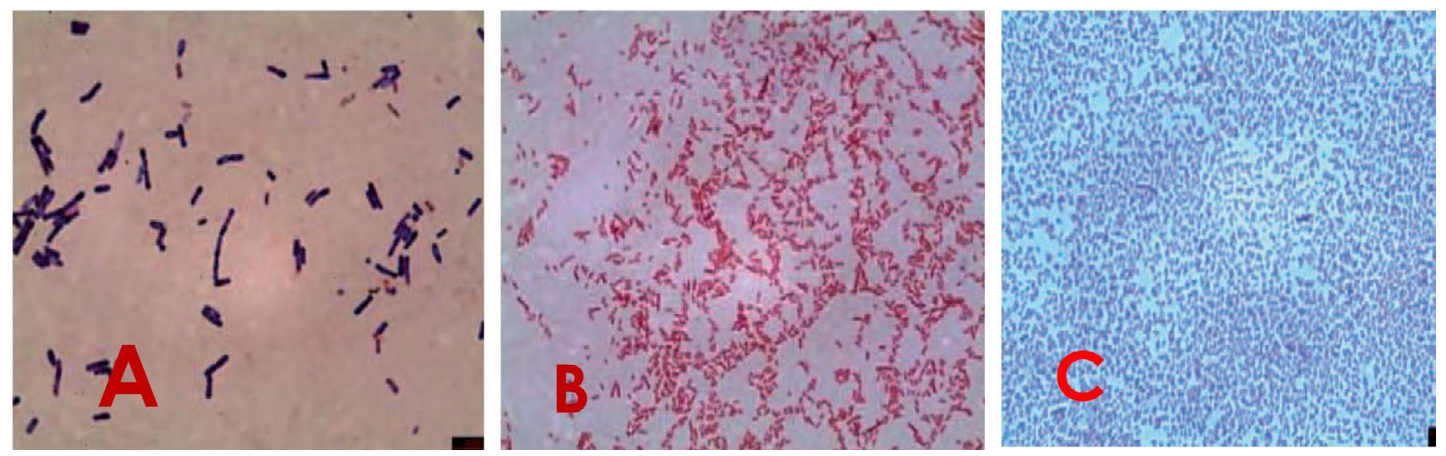

Fig. 2. Microscopic shape of some example of isolated bacteria : A: Bacillus subtilis, (gram stains) (1000X). Bacteria appear gram positive bacilli, B: Sphingomonas paucimobilis, Bacteria appear gram positive rod, C: Staphylococcus lentus, Bacteria appear gram positive cocci.

Table 6. Bacterial species isolated from the sediments of studying station

\begin{tabular}{llll}
\hline Bacteria & $\begin{array}{l}\text { Gram } \\
\text { stain }\end{array}$ & Shape & Color \\
& & \\
\hline Sphingomonas paucimobilis & - & Rod shape & Yellow \\
Bacillus subtilis & + & Rod shape & Gray-white \\
Pseudomonas aeruginosa & - & Rode shape & Green \\
Streptococcus thoraltensis & + & Cocci & Yellow \\
Staphylococcus lentus & + & Cocci & Yellow \\
Leuconostoc cremoris & + & Bacilli & White \\
Leuconostoc mesenteroides & + & Elongated & White \\
& & cocci & \\
\hline
\end{tabular}

Since fungi can tolerate higher concentration of heavy metals and other pollutant, they play important role as bioindicators for different pollutant in the water ecosystem ${ }^{43}$. In the present study, nine fungal species were isolated from the surface sediments (Table 7, Fig. 3). Most

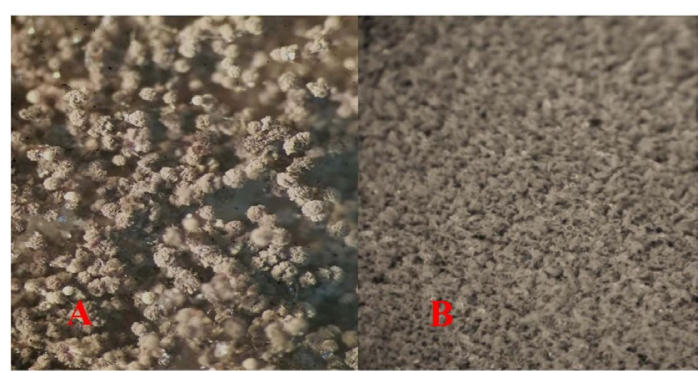

Fig. 3. Microscopic shape of some example of Cultures of some isolated fungi, a: Aspergillus niger, b: Penicillium sp. (16X) of the isolated fungi have been studied previously and found to be good bioindicators for heavy metals pollution in water ecosystem ${ }^{43,44}$.

Table 7. Fungal species isolated from the sediments of studying station

\begin{tabular}{lc}
\hline No. & Type of fungi \\
\hline 1 & Aspergillus terreus \\
2 & Aspergillus fumigatus \\
3 & Aspergillus niger \\
4 & Curvularia sp. \\
5 & Eurotium cristatus \\
6 & Talaromyces flavus \\
7 & Mucor sp. \\
8 & Rhizopus sp. \\
9 & Trichoderma sp. \\
10 & Dichotomomyces cejpii \\
11 & Penicillium spp. \\
\hline
\end{tabular}




\section{CONCLUSION}

Bacteria and fungi recently are being used as vital indicators for water pollution with heavy metals and other pollutants. They represent the modern and the successful means as they give accurate indication of the water pollution state. In addition to their presence in the environment, it reflects the health status of the environment in terms of the self-treatment possibility of the environment from those pollutants.

\section{ACKNOWLEDGMENTS}

The authors are thankful to Marine Science Center, special bacterial lab for all support.

\section{CONFLICT OF INTEREST}

The authors declare that there is no conflict of interest.

\section{AUTHORS' CONTRIBUTION}

All Authors contributed to the design of the research experiment, collecting samples, conducting tests, and producing the results in a manner appropriate for publication. RSJ wrote the manuscript and prepared it for the publication.

\section{FUNDING}

None.

\section{DATA AVAILABILITY}

All datasets generated or analyzed during this study are included in the manuscript.

\section{ETHICS STATEMENT}

This article does not contain any studies with human participants or animals performed by any of the authors.

\section{REFERENCES}

1. Croquer A, Bone D, Bastidas C, Ramos R, Garcia E. Monitoring coastal pollution associated with the largest oil refinery complex of Venezuela. PeerJ. 2016;4:e2171. doi: 10.7717/peerj.2171

2. Al-Asadi SAR, Al-Qurnawi WS, Al Hawash AB, Ghalib HB, Alkhlifa N-HA. Water quality and impacting factors on heavy metals levels in Shatt Al-Arab River, Basra, Iraq. Appl Water Sci. 2020;10:103. doi: 10.1007/s13201020-01196-1

3. Edokpayi JN, Odiyo JO, Popoola OE, Msagati TAM. Assessment of trace metals contamination of surface water and sediment: A case study of Mvudi River South Africa. Sustain. 2016;8(2):135. doi: 10.3390/

\section{su8020135}

4. I-khuzaie DKK. Assessment of Sediment Quality Collected from AL-Hawizeh. J Int acadimic Res multidiscipinary. 2013;8(1):27-38

5. Sumampouw OJ, Risjani Y. Bacteria as Indicators of Environmental Pollution: Review. Int J Ecosyst. 2014;4(6):251-258. doi: 10.5923/j.ije.20140406.03

6. Fauzi $\mathrm{H}$, Idris KM. The Relationship of CSR and Financial Performance: New Evidence from Indonesian Companies. Issues Soc Environ Account. 2007;1(1):149159. doi: 10.22164/isea.v3i1.38

7. Karbasdehi VN, Dobaradaran S, Nabipour I, et al. Indicator bacteria community in seawater and coastal sediment: The Persian Gulf as a case. J Environ Heal Sci Eng. 2017;15:6. doi: 10.1186/s40201-017-0266-2

8. Pachepsky YA, Shelton DR. Escherichia coli and fecal coliforms in freshwater and estuarine sediments. Crit Rev Environ Sci Technol. 2011;41(12):1067-1110. doi: 10.1080/10643380903392718

9. Chu D. Effects of heavy metals on soil microbial community. IOP Conf Ser Earth Environ Sci. 2018;113(1). doi: 10.1088/1755-1315/113/1/012009

10. Oladipo OG, Awotoye OO, Olayinka A, Bezuidenhout CC, Maboeta MS. Heavy metal tolerance traits of filamentous fungi isolated from gold and gemstone mining sites. Brazilian J Microbiol. 2018;49(1):29-37. doi: 10.1016/j.bjm.2017.06.003

11. Osu C, Okereke VC. Heavy Metals Contamination in Relation to Microbial Counts in Soils of Automobile Mechanic Workshops, Port Harcourt Metropolis, Rivers States, Nigeria. J Am Sci. 2010;6(9):236-241.

12. Ataikiru TL, Okorhi-damisa BF, Akpaiboh JI. Microbial community structure of an oil polluted site in Effurun, Nigeria. Int Res J Public Environ Heal. 2017;4(3):41-47.

13. Bhasheer SK, Umavathi S, Banupriya D, Thangavel M, Thangam Y. Diversity of diesel degrading bacteria from a hydrocarbon contaminated soil. Int J Curr Microbiol App/ Sci. 2014;3(11):363-369.

14. UN-ESCWA and BGR (United Nations Economic and Social Commission for Western Asia; Bundesanstalt für Geowissenschaften und Rohstoffe). Inventory of Shared Water Resources in Western Asia. Beirut, 2013, p56.

15. Hussain NA,AL-Najar HH, AL-Saad HT, Yousif UH and AL-Saboonchi AZ. Shatt AL-Arab scientific study. University of Basrah, Marine Science center, Publication No.10: (1991).

16. Chester, R, and Voutsinou FG. The initial assessment of trace metal pollution in coastal sediments. Mar Pollut Bull. 1981;12(3):84-91. doi: 10.1016/0025326X(81)90198-3

17. Sturgeon RE, Desaulincrs JA, Berman SS, Russell DS. Determination of trace metals in estuarine sediment by graphite furnace atomic absorption spectrophotometry. Anal Chem Acta. 1982;134:288291. doi: 10.1016/S0003-2670(01)84198-2

18. Al-Shamsi ZSR, Mohammed AH, Al-saad HT. Heavy Metals in Residual Sediments Core Along Shatt AL-Arab Estuary. J Pharm, Chem Biol Sci. 2016;4(3):440-449.

19. Goutx $M$, Saliot $A$. Relationship between dissolved and Particulate Relationship between dissolved and Particulate fatty acid and hydrocarbons, Chlorophyll 
(a) and zooplankton biomass in Ville Franche Bay, Mediterranean Sea. Mar Chem. 1980;8:299 - 318. doi: 10.1016/0304-4203(80)90019-5

20. De Hoog GS, Guarro J. Atlas of Clinical Fungi. Second edition. Centraalbureau voor Schimmelcultures; Reus: Universitat Rovira i Virgili, Netherlands. 1995.

21. Seifert KA, Gams W. The genera of Hyphomycetes 2011 update. Persoonia Mol Phylogeny Evol Fungi. 2011;27:119-129. doi: 10.3767/003158511X617435

22. Rinawati $R$, Takada H. Distribution and source of sedimentary polycyclic aromatic hydrocarbon (PAHs) in river sediment of Jakarta. Indones J Chem. 2017;17(3):394-400. doi: 10.22146/ijc.26837

23. Budzinski H, Jones I, Bellocq J, Pierard C, Garrigues P. Evaluation of sediment contamination by polycyclic aromatic hydrocarbons in the Gironde estuary. Mar Chem. 1997;58(1-2):85-97. doi: 10.1016/S03044203(97)00028-5

24. Chatterjee M, Silva Filho EV, Sarkar SK, et al. Distribution and possible source of trace elements in the sediment cores of a tropical macrotidal estuary and their ecotoxicological significance. Environ Int. 2007;33(3):346-356. doi: 10.1016/j. envint.2006.11.013

25. Jaafar RS, Hammood AY, Abdulnabi A, Alhello AZ, Al-Saad HT. An integrative study to determine the Bioavailability of heavy metals in the soil. Ecol Environ Conserv. 2019;25(4):1524-1531.

26. Sabbir W, Rahman MZ, Hasan MM, Khan MN, Ray S. Assessment of Heavy Metals In River Water, Sediment and Fish Mussel In Rupsh River Under Khulan District, Bangladesh. Int J Exp Agric. 2018;8(1):1-5.

27. Bamidele OOI, Agunbiade FO, Adebowale KO. Metal speciation in sediments from crude oil prospecting in the coastal area of Ondo State, Nigeria. Earth Sci Res J. 2013;17(1):41-51.

28. Al-Khafaji BY. Trace metals in water, sediments and fishes from Shatt Al-Arab Estuary North-West Arabian Gulf,Ph.D. Thesis, Biology Dep. , College of Education, Univ. Basrah. 1996: 131

29. Al-Saffie AGA. Study of some of Heavy elements in Water, Sediments and Phytoplankton in Shatt Al-Arab river,M.Sc. Thesis. University of Basrah, college of science, Biology Department. 2005: 85.

30. AlQarooni IHM. Estimation of some heavy metals concentrations in water, sediment and bioaccumulation in some invertebrates of Shatt AlArab River and Shatt Al-Basrah canal, southern Iraq ". Ph.D. Thesis, Biology Dep., College of Education , Univ. Basrah,2011: 243.

31. Al-Shmery AY. Estimation of some Heavy Metals in clams, sediments and water from Shatt Al-Arab and treatment by porcellanite rocks,M.Sc. Thesis, Chemistry Depart. College Of Education For Pure Science, Unive. Basrah. 2013:100.

32. Al-tawash B, Al-lafta H, Merkel B. Multivariate
Statistical Evaluation of Major and Trace Elements in Shatt Al-Arab Sediments, Southern Iraq. J Environ Earth Sci. 2013;3(11):146-155.

33. Al-Hejuje MM. Application of water quality and pollution indices to evaluate the water and sediments status in the middle part of Shatt Al-Arab River. Published online 2015.

34. Al-Mahana DS. "Distribution and sources of total Hydrocarbons, N-AlKane and Poly Cyclic Aromatic compounds in sediment cores of Shatt Al-Arab coast, Khor Al-Zubair and Um- Qaser". M.Sc. thesis. Department of Geology, College of Science, University of Basrah, Iraq 2015.

35. Al-Shamsi ZSR. Heavy Metals in Sediments Core Along The Shatt AL-Arab Estuary. 2017.

36. Al-hejuje MM, Al-saad HT, Hussain NA. Application of geo-accumulation index (I-geo) for assessment the sediments contamination with heavy metals at Shatt Al-Arab River-Iraq. J Sci Eng Res. 2018;5(2):342-351 www.jsaer.com

37. Parmar TK, Rawtani D, Agrawal YK. Bioindicators: the natural indicator of environmental pollution. Front Life Sci. 2016;9(2):110-118. doi: 10.1080/21553769.2016.1162753

38. Zaghloul A, Saber M, Gadow S, Awad F. Biological indicators for pollution detection in terrestrial and aquatic ecosystems. Bull Natl Res Cent. 2020;44:127. doi: 10.1186/s42269-020-00385-x

39. Kalkan S, Altug G. Bio-indicator bacteria \& environmental variables of the coastal zones:The example of the Gulluk Bay, Aegean Sea, Turkey. Mar Pollut Bull. 2015;95(1):380-384. doi: 10.1016/j. marpolbul.2015.04.017

40. Jaafar R. Bioremediation of lead and cadmium and the strive role of Pediococcus pentosaceus probiotic. Iraqi J Vet Sci. 2020;34(1):51-57. doi: 10.33899/ ijvs.2019.125581.1092

41. Srut M, Menke S, Hockner M, Sommer S. Earthworms and cadmium - Heavy metal resistant gut bacteria as indicators for heavy metal pollution in soils? Ecotoxicol Environ Saf. 2019;171:843-853. doi: 10.1016/j. ecoenv.2018.12.102

42. Nwagwu EC, Yilwa VM, Egbe NE, Onwumere GB. Isolation and characterization of heavy metal tolerant bacteria from Panteka stream, Kaduna, Nigeria and their potential for bioremediation. African J Biotechnol. 2017;16(1):32-40. doi: 10.5897/ajb2016.15676

43. Romero MC, Reinoso EH, Urrutia MI, Kiernan AM. Biosorption of heavy metals by Talaromyces helicus: a trained fungus for copper and biphenyl detoxification. Electron J Biotechnol. 2006;9(3):221-226. doi: 10.2225/ vol9-issue3-fulltext-11

44. Siddiquee S, Rovina K, Azad S Al. Heavy Metal Contaminants Removal from Wastewater Using the Potential Filamentous Fungi Biomass: A Review. J Microb Biochem Technol. 2015;07(06):384-393. doi: 10.4172/1948-5948.1000243 